\title{
Toxicity Effects of Methanolic Extract of Euphorbia hirta-Honey Mixture in Albino Rats
}

\author{
Ifeanyi Peter Onyeka ${ }^{1}$, Mohammed M Suleiman ${ }^{2}$ and Sunday P Bako ${ }^{3}$ \\ ${ }^{1}$ Department of Biological Sciences, Faculty of Science, Ahmadu Bello University Zaria, Nigeria \\ ${ }^{2}$ Department of Veterinary Pharmacology and Toxicology, Faculty of Veterinary Medicine, Ahmadu Bello University Zaria, Nigeria \\ ${ }^{3}$ Department of Biological Sciences, Faculty of Science, Ahmadu Bello University Zaria, Nigeria
}

*Corresponding author:Ifeanyi P Onyeka, Department of Biological Sciences, Faculty of Science, Ahmadu Bello University Zaria, Nigeria, Tel: +23-48063910820; Email: anyinoble2get@gmail.com

Received date: December 11, 2017; Accepted date: January 06, 2018; Published date: January 12, 2018

Copyright: (c) 2018 Onyeka IP, et al. This is an open-access article distributed under the terms of the Creative Commons Attribution License, which permits unrestricted use, distribution and reproduction in any medium, provided the original author and source are credited.

\begin{abstract}
The Igbo people of the South-eastern part of Nigeria claims that a combination of Ehirta and honey has therapeutic effect for Ulcer. The study was designed to scientifically evaluate the phytochemical composition of $E$. hirta and the safety of the phytomedicine. Nine hundred gram (900 g) of $E$. hirta gave an average yield of $49.05 \mathrm{~g}$ of the extract and this gave percentage yield of $5.45 \%$ when extracted with continuous extraction process of Soxhlet apparatus. Phytochemical screenings of E. hirta showed that the extract contains alkaloids, Tannins, Saponins, Glycosides, Flavonoids and Unsaturated steroids. Acute toxicity studies showed that LD $_{50}$ was greater than 5000 $\mathrm{mg} / \mathrm{kg}$. The phytomedicine of $E$. hirta combined with did not produce significant changes in the blood biochemical and haematological parameters. Though slight reductions were witnessed in blood ALT the phytomedicine drugs has no significant effect on the liver and other vital organs like the kidney, the heart, spleen, intestine and the brain except the lungs that witnessed slight alveoli congestion. The study revealed that $E$. hirta combined with honey is safe for consumption.
\end{abstract}

Keywords: Toxicity; Euphorbia hirta; Honey; Sub chronic toxicity

\section{Introduction}

Herbal medicine also known as phytomedicine provides alternative source of drug for treatment of numerous diseases. Plants occupy a very important place in modern medicine as they are used as either raw materials for drugs or as a template for discovering and synthesis of drugs. The use of plants in medicine is based on the premise that they contain natural substances that can promote health and alleviate illness [1].

Plant based drugs when harnessed properly could be a source of relatively clean, safe, and effective drugs for treatment of diseases with absence or less adverse effect. Ogbonnia [2] argued that the discovery of active compounds derived from plants could act as potential therapeutic weapons against various human, animal and even plant diseases in addition to their food and nutritional values and this has made plant become invaluable and indispensable to human and animal lives. This benefits has made plant based drugs and other plant based combinations therapies to be viewed as a potential source of alternative drugs that is relatively clean, cheap and effective with untapped potential. Herbal medicine either as an extract, pure compound, or as a derivative, offers unlimited opportunities for the discovery of new drugs [3]. Herbal medicine may have multiple therapeutical activities and could be used in treatment of variety of disease conditions [4]. Thus a single herb may have varied traditional therapeutic claims as a result of various organic bioactive Phytochemicals present in the herb. However, herbal medicine has been renowned as the most common form of alternative medicine and is used by more than $60 \%$ of the world populations both in the developing countries and in the developed countries where modern medicine are predominantly used [2,5].

In developing countries the usage of herbal medicines by traditional practitioners for the treatment of diseases remains the main stay of health care system and is gaining increasing popularity especially among the rural populace in the developing countries [6]. The surge in the use of herbal medicine in modern day as alternative medicine has led to increase in demands of herbal drugs. This revolutionary demand in herbal drugs and herbal preparations has been attributed to factors such as the misconception that plant product are natural devoid of adverse and toxic effect associated with conventional medicine. Another reason for the surge in the use of traditional medicine is that certain herbal medicines are peculiar to certain traditions. There is exclusive use of herbal drugs in the management of certain ailments in most Nigeria rural communities and other developing countries of the world [7] like China and India.

However, herbal medicine usage could pose some latent toxic effect and this could be seen as a potential risk to over $60 \%$ of the populace using herbal drugs as sources of health care need. Herbal preparations and herbs when administered in certain disease condition may pose a toxic threat and there is need to evaluate safety, quantity (dosage) and therapeutic significances of these herbs. Warnings about the potential toxicity of such herbal therapies demands that the practitioners should be kept abreast of the reported incidence of renal and hepatic toxicity associated with the ingestion of the of the medicinal herbs [8]. Increase morbidity and mortality associated with use of herbs or the so called traditional medicines has raised universal attention in the last few years [9]. However, upon exposure, the clinical toxicity may vary from mild to severe and sometimes to life threatening making the safety and toxicity evaluations of herbal preparations imperative. There is 
however, little or no information or evidence on the toxicity of certain herbal drug preparations to the consumers $[10,11]$ and these has raised pertinent health concerns to the stakeholders in health sector. Recent reviews and findings has shown that plants based drugs applied in traditional medicine have varying level of adverse toxic effects. These and many other pertinent concerns on the safety of the plant based drugs have necessitated the need to evaluate the toxicological effect of any medicinal plant extract or herbal formulations intended to be used as drugs or nutraceuticals for animals and humans through gross evaluation of the toxicological activities of the herbal preparations.

Traditionally, honey combined with Euphorbia hirta has been use by Igbo people of south eastern part of Nigeria for the treatment of ulcer and other stomach problems [7]. E. hirta is a widely used herb in areas where it is found, including the tropical part of Africa. In the south eastern part of Nigeria the plant is call 'iruru agwo' (i.e. snake weed), and is locally used for the treatment of snakebite and ulcer.

Euphorbia hirta belongs to the genus Euphorbia, family Euphorbiaceae. It is characterized by the presence of white milky latex which is more or less toxic $[12,13]$. It is usually erect, slender-stemmed, and spreading up to $80 \mathrm{~cm}$ tall (although sometimes it is seen lying down) [14]. It is an annual broad-leaved herb that has a hairy stem with many branches from the base to the top. The leaves are opposite, elliptical, oblong or oblong-lanceolate, with a faintly tooted margin.

Studies had revealed the anti-bacterial [15], anti-helminthic, antiretroviral [16], anti-plasmodial, anti-amoebic [17], anti-oxidant [18], sedative, anti-spasmodic, anti-fungal [19] and anti-malaria [14] activities of Euphorbia hirta. The plant has been reported to contain alkaloids, triterpenoids, phytosterols, tannins, polyphenols and flavonoids [13]. It is among the group of popular herbs used traditionally for the treatment of various diseases such as intestinal parasites, diarrohea, peptic ulcers, heartburn, vomiting, amoebic dysentery, asthma, bronchitis, hay fever, laryngeal spasms, emphysema, coughs, colds, kidney stones, menstrual problems, sterility and veneral diseases [14].

Honey as a product of both plant and bee has been used as a medicine since time immemorial throughout ages. Honey is a nectar collected by bees from a wide variety of plants that is concentrated by evaporation of water to form a saturated or supersaturated solution of sugars consisting typically of $17 \%$ water, $38 \%$ fructose, $31 \%$ glucose, $10 \%$ other sugars and a wide range of micro-nutrients (vitamin, amino acids and minerals) with a $\mathrm{p}^{\mathrm{H}}$ below 4 [20].

Bees during processing of nectar inject and add some enzymes like catalase and invertase which makes honey very a significant neutraceutical condiment. Invertase converts sucrose in the nectar into glucose and fructose, so that the sucrose content of honey is typically only $1 \%$ of the total sugar content [20] while another enzyme called glucose oxidase forms gluconic acid and hydrogen peroxide from the glucose. The presences of catalase in honey are able to promote protection against the toxic effects of oxygen-derived free radicals and abolish the increment of endothelial cell permeability [21].

\section{Materials and Methods}

\section{Plant collection and preparation}

Fresh whole plant (leaves and the stem) of E. hirta were collected from the main campus of Ahmadu Bello University, Zaria, Kaduna state, Nigeria. The plant was identified at the herbarium, Department of Biological Sciences, A.B.U. Zaria. A voucher specimen number 583 was deposited. The plant materials were air dried at room temperature 10-14 days during the dry weather condition. The air-dried plant was ground and $300 \mathrm{~g}$ of the powder was extracted using $2700 \mathrm{ml}$ of $70 \%$ methanol by continuous extraction in a Soxhlet apparatus. The extract was concentrated to dryness using a water bath kept at $30^{\circ} \mathrm{C}-45^{\circ} \mathrm{C}$. The concentrated extract was scrapped into a sample bottle and kept in desiccators until required.

\section{Phytochemical analysis of $E$. hirta}

Phytochemical analysis was conducted using method described by Trease and Evans [22] to determine the presence of secondary metabolites or active components in E. hirta. About $1 \mathrm{~g}$ of the extract was dissolved in $10 \mathrm{ml}$ Tween 80 solution as stock.

\section{Honey and drug preparation}

Honey used was collected from Forest Research Institute of Nigeria, Kaduna out-station, Kaduna State, Nigeria. The honey used in this study was pure, unprocessed, unboiled, multifloral apiary honey. The trees around the apiary were Senna siamea, Thevitia peruviana. The honey was filtered before use. The stock of honey combined with $E$. hirta as a drug was prepared using $25 \% \mathrm{w} / \mathrm{v}$ of the extract in honey to make a concentration of $250 \mathrm{mg} / \mathrm{ml}$ of honey. The stock was however further diluted to make a concentration of $100 \mathrm{mg} / \mathrm{ml}$ for doses of 10 and 100 and $200 \mathrm{mg} / \mathrm{kg}$.

\section{Animals}

Healthy adult albino Wistar (103) rats were obtained from the Department of Veterinary Pharmacology and Toxicology, Ahmadu Bello University, Zaria. The animals were maintained at room temperature and humidity $\left(25^{\circ} \mathrm{C}, 70 \%\right.$ Relative humidity) and allowed to acclimatize for 2 weeks. All the animals were fed with standard pelleted diet and water ad libitum.

\section{Acute toxicity test}

The acute toxicity test to determine the $\mathrm{LD}_{50}$ as an index of safety of the extract and honey combination was done in 2 phases as described by Lorke [23]. Briefly, nine animals (rats) were randomly allocated into 3 groups of 3 rats each. Animals in group 1, 2 and 3 were given 10, 100, and $1000 \mathrm{mg} / \mathrm{kg}$ body weights respectively of the extract and honey mixture through the oral route.

Animals were therefore monitored for signs of toxicity and mortality for 2 days (48 hours). Signs of toxicity and pathological findings observed were recorded appropriately. All the animals survived so the extract and honey mixture was further subjected to acute toxicity test with higher doses in the second trial.

In the second trial, 4 animals were randomly allocated to 4 groups of one animal each. Animals in group 1, 2, 3 and 4 were given 1200, 1600,2900 and $5000 \mathrm{mg} / \mathrm{kg}$ body weight, respectively of the extract combined with honey.

\section{Sub-chronic toxicity test}

Adult wistar albino rats of either sex were used. Forty animals were divided into 4 groups of 10 animals each. Rats in group 1, 2 and 3 were given the extract combined with honey at doses of 200, 400 and 800 $\mathrm{mg} / \mathrm{kg}$ body weight, respectively. The animals in the fourth group 
Page 3 of 8

received only distilled water at $5 \mathrm{ml} / \mathrm{kg}$ body weight and served as untreated control.

All treatment was given by oral route once a day for 28 days [24]. The animals were observed for signs of toxicity (mortality, nervousness, and other physiological changes) during the experimental period. Animals were weighed every other day, from the start of the experiment. The Packed cell volume of each animal was measured every week. On the 28th day post treatment, animals were fasted for 24 hours but allowed free access to water. Thereafter, animals were anaesthetized with diethyl ether and $8 \mathrm{ml}$ blood was collected by retro orbital puncture [25]. About $3 \mathrm{ml}$ of the blood was put into a container with EDTA as anti-coagulant while the remaining $5 \mathrm{ml}$ was allowed to clot so as to obtain the serum. The plasma and serum were used for hematological and biochemical analysis respectively. All animals were sacrificed and their internal organs (brain, heart, liver, lungs, kidney and spleen and intestine) were collected weighed, blotted dry and the relative organ weight (weight of organ in proportion to the total body weight of each rat) was recorded. The internal organs were fixed in a buffer containing $10 \%$ formaldehyde for histological analysis.

\section{Hematological and biochemical analyses}

Using the collected blood plasma, the Red Blood Cell Count (RBC), White Blood Cell Count (WBC), Haemoglobin (Hb), Mean Corpuscular Volume (MCV), Mean Corpuscular Haemoglobin Concentration (MCHC) and Packed Cell Volume (PCV), were analyzed using standard protocols [26].

Clotted blood, (blood collected without anti-coagulant) was centrifuged at $3000 \mathrm{~g}$ for $5 \mathrm{~min}$. Serum were separated and stored at $4^{\circ} \mathrm{C}$ until required for determination of biochemical parameters like, Aspartate Amino-Transferase (AST), Alanine Amino Transferase (ALT), Total Cholesterol (TC), Alkaline Phosphatase (ALP), Total Bilirubin (TB), Conjugated Bilirubin (CB) and Total Protein (TP) were analysed. Similarly, the concentrations of creatinine, urea, uric acid, $\mathrm{Na}$ ${ }^{+}, \mathrm{Cl}^{-}, \mathrm{K}^{+}$and $\mathrm{Ca}^{2+}$ were determined from each serum sample using automated spectrum analyzer machine SELECTRA XL (Vita Scientific Netherlands) at Ahmadu Bello University Teaching Hospital, Shika, Zaria, Kaduna State, Nigeria.

\section{Data analysis}

All statistical analysis were done using Graphical Prism version 4.0 for window from Graphpad software, San Diego, USA. Data obtained were analyzed using one way analysis of variance. Where significant differences were observed, the Turkey Post Hoc-test was used to identify and compare differences between groups. Values were considered significant if $\mathrm{P}<0.05$ and 0.01 . Duncan multiple range test was used to compare the means across each treatment group with untreated group.

\section{Results and Discussion}

\section{Extract yield}

Nine hundred gram (900 g) of E. hirta gave an average yield of 49.05 $\mathrm{g}$ of the extract and this gave percentage yield of $5.45 \%$ when extracted with continuous extraction process of Soxhlet apparatus.

\section{Phytochemical screening}

The result of the phytochemical evaluation revealed the presence of all the vital phytochemicals except triterpenes and anthraquinones. However the plant revealed the presence of alkaloids, saponins, tannins, glycosides, flavonoids, carbohydrates and unsaturated steroids.

\section{Acute toxicity testing}

The Result for the acute toxicity studies of E. hirta extract in combination with honey is shown in Table 1 . The extract in combination with honey showed no sign of mortality up to doses of $5000 \mathrm{mg} / \mathrm{kg}$. Physical examinations of the rats showed no sign of changes in the skin, fur, eyes, mucus membrane, behavior patterns, salivation and no diarrhoea of the rats.

\section{Sub chronic toxicity studies}

Body weight: The result of toxic effect of $E$. hirta combined with honey on the body weight of rats is shown in Figure 1. All the rats (both the treated and control) had normal growth without any retardation, as depicted in Figures 1 to 3. The extract of E. hirta combined with honey at doses of 200,400 and $800 \mathrm{mg} / \mathrm{kg}$ did not produce any significant change in body weight of rats up to 8 days post-administration. However, there was slight significant $(\mathrm{P}<0.05)$ reduction in body weight of rats treated with extract and honey combination at $200 \mathrm{mg} / \mathrm{kg}$ started from day 9 till 27 post administration after administration at dose of 200,400 and $800 \mathrm{mg} / \mathrm{kg}$ when compared with the untreated control that received distilled water.

Organ weight: The result of the toxicity effect of the $E$. hirta combined with honey on the internal organs of the rats is shown in Table 2. The effect of the treatment (plant extract combined with honey) on the vital organs of the brain, the liver, the kidney, the spleen, the intestines, and the hearts at different doses of $200 \mathrm{mg} / \mathrm{kg}, 400$ $\mathrm{mg} / \mathrm{kg}$ and $800 \mathrm{mg} / \mathrm{kg}$ body weights combined with honey revealed that, there was no significant differences $(\mathrm{P}<0.01)$ between the treatments and the control group in all the organs (Table 2), except the lungs which showed significant differences $(\mathrm{P}<0.05)$ between the control and the treatment groups (Table 2).

Biochemical parameters: The result of the effect of the crude methanol extract of $E$. hirta extract combined with honey on blood biochemical parameters of rats are shown in Table 3. The extract combined with honey showed significance reduction $(\mathrm{P}<0.05)$ in blood Alanine Aminotransferase (ALT) of the treated rats at doses of 200, 400 and $800 \mathrm{mg} / \mathrm{kg}$ body weight respectively (Table 3 ), when compared with the control. The result further revealed no significant effect on the other liver enzymes of rats though the extract combined with honey slightly reduced $(\mathrm{P}<0.01)$ Aspartate Aminotransferase $(\mathrm{AST})$ of rats when compared with untreated control. Similarly, the extract combined with honey had no significant effect on the Alkaline Phosphotase (ALP) of the rats $(\mathrm{P}<0.01)$ though the untreated control had a slight higher value of ALP. The effect of the extract combined with honey on Creatinine of the rats, showed slight significant increase $(\mathrm{P}<0.01)$ at doses of 200 and $400 \mathrm{mg} / \mathrm{kg}$ when compared with the untreated control was comparable with that of $800 \mathrm{mg} / \mathrm{kg}$.

The effect of the extract combined with honey on Urea of the rats, showed increase at doses of 400 and $800 \mathrm{mg} / \mathrm{kg}$. The rats treated with $200 \mathrm{mg} / \mathrm{kg}$ showed decrease significant $(\mathrm{P}<0.01)$ effect with value of 
Citation: Onyeka IP, Suleiman MM, Bako SP (2018) Toxicity Effects of Methanolic Extract of Euphorbia hirta-Honey Mixture in Albino Rats. J

Page 4 of 8

$5.89 \pm 0.18$, when compared with the rats that received $400 \mathrm{mg} / \mathrm{kg}$ and the untreated control. The extract combined with honey had no Significant $(\mathrm{P}<0.01)$ effect on the blood cholesterol (though showed reduction in values among the treatments) of the rats at doses of 200 , 400 and $800 \mathrm{mg} / \mathrm{kg}$ when compared with untreated control. The extract combined with honey had no significant $(\mathrm{P}<0.001)$ effect on the blood: potassium $\left(\mathrm{K}^{+}\right)$(though slight reduction was recorded), total protein (TP), sodium $\left(\mathrm{Na}^{+}\right)$chlorine $\left(\mathrm{Cl}^{-}\right)$, uric acid and calcium $\left(\mathrm{Ca}^{2+}\right)$.

\section{Blood haematological parameters}

The results of the effect of crude methanol extracts of E. hirta combined with honey on blood haematological parameters are shown in Table 4 the result of the toxicity effect of crude methanol extract of E. hirta combined with honey on the blood haematological parameters revealed that the extract has effect on the blood haematological parameters except on the MCHC. The plant extract at $200 \mathrm{mg} / \mathrm{kg}$ (14.45 \pm 0.32) combined with honey showed slight significant reduction $(\mathrm{P}<0.01)$ on the blood haemoglobin of rats compared with that of 400 and $800 \mathrm{mg} / \mathrm{kg}$ with values of $15.86 \pm 0.33$ and $15.37 \pm 0.42$ and untreated control group (Table 4). The result further showed a significant reduction $(\mathrm{P}<0.01)$ in red blood cell count of rats at doses of $200(7.88 \pm 0.30)$ and $800 \mathrm{mg} / \mathrm{kg}(7.89 \pm 0.15)$ when compared with the untreated control.

\begin{tabular}{|c|c|c|}
\hline Dosage $\mathrm{mg} / \mathbf{k g}$ & No of animals & Mortality ratio \\
\hline 10 & 3 & $0 / 3$ \\
\hline 100 & 3 & $0 / 3$ \\
\hline 1000 & 3 & $0 / 3$ \\
\hline 1200 & 1 & $0 / 1$ \\
\hline 1600 & 1 & $0 / 1$ \\
\hline 2900 & 1 & $0 / 1$ \\
\hline 5000 & 1 & $0 / 1$ \\
\hline
\end{tabular}

Table 1: Mortality Effect of different doses of methanol extract of Euphorbia hirta combined with honey on rats.

\begin{tabular}{|c|c|c|c|c|}
\hline \multirow[t]{2}{*}{ Organ } & \multicolumn{4}{|l|}{ Dose (mg/kg) } \\
\hline & 200 & 400 & 800 & DW5 ml/kg \\
\hline Brain (g) & $1.26 \pm 0.03^{a}$ & $1.43 \pm 0.07^{a}$ & $1.28 \pm 0.08^{a}$ & $1.34 \pm 0.08^{a}$ \\
\hline Heart (g) & $0.64 \pm 0.02^{a}$ & $0.60 \pm 0.02^{a}$ & $0.58 \pm 0.01^{a}$ & $0.65 \pm 0.04^{a}$ \\
\hline Liver (g) & $5.43 \pm 0.19^{a}$ & $5.08 \pm 0.19^{a}$ & $5.32 \pm 0.25^{a}$ & $5.34 \pm 0.19^{a}$ \\
\hline Lungs (g) & $1.58 \pm 0.13^{\mathrm{ab}}$ & $1.43 \pm 0.12^{\mathrm{ab}}$ & $1.29 \pm 0.09^{b}$ & $1.75 \pm 0.15^{a}$ \\
\hline Kidney (g) & $1.09 \pm 0.05^{a}$ & $1.00 \pm 0.04^{a}$ & $1.07 \pm 0.09^{a}$ & $1.09 \pm 0.06^{a}$ \\
\hline Spleen (g) & $0.79 \pm 0.03^{a}$ & $0.77 \pm 0.04^{\mathrm{a}}$ & $0.81 \pm 0.07^{a}$ & $0.84 \pm 0.06^{a}$ \\
\hline Intestine (g) & $0.48 \pm 0.06^{a}$ & $0.47 \pm 0.03^{a}$ & $0.40 \pm 0.03^{a}$ & $0.50 \pm 0.02^{a}$ \\
\hline
\end{tabular}

Table 2: Effect of the crude methanol extract of Euphorbia hirta combined with honey on the weights of internal organs of rats. 
Citation: Onyeka IP, Suleiman MM, Bako SP (2018) Toxicity Effects of Methanolic Extract of Euphorbia hirta-Honey Mixture in Albino Rats. J

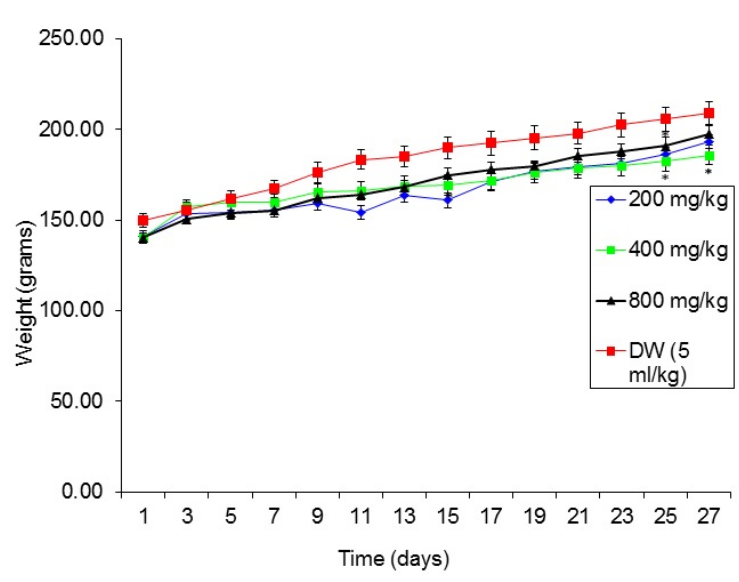

Figure 1: Effect of E. hirta combined with honey at 200, 400 and 800 $\mathrm{mg} / \mathrm{kg}$ on the body weight of rats. Means with asterisk are significantly different $(\mathrm{P}<0.01)$ when compared with the control that received distilled water.

\begin{tabular}{|c|c|c|c|c|}
\hline \multirow[t]{2}{*}{ Biochemical parameter } & \multicolumn{4}{|c|}{ Treatment (mg/kg) } \\
\hline & 200 & 400 & 800 & DW5 ml/kg \\
\hline ALT (U/L) & $59.60 \pm 4.78^{\mathrm{ab}}$ & $54.33 \pm 1.91^{b}$ & $58.00 \pm 3.73^{a b}$ & $69.00 \pm 3.18^{a}$ \\
\hline AST (U/L) & $78.50 \pm 5.03^{a}$ & $82.33 \pm 2.98^{a}$ & $78.63 \pm 5.12^{a}$ & $83.20 \pm 2.81^{\mathrm{a}}$ \\
\hline ALP (U/L) & $68.10 \pm 3.58^{a}$ & $67.11 \pm 3.02^{a}$ & $71.88 \pm 4.07^{a}$ & $74.00 \pm 2.95^{\mathrm{a}}$ \\
\hline Urea (mg/dl) & $5.89 \pm 0.18^{b}$ & $6.78 \pm 0.22^{a}$ & $6.35 \pm 0.25^{\mathrm{ab}}$ & $6.07 \pm 0.18^{b}$ \\
\hline Creat (mg/dl) & $58.20 \pm 1.30^{\mathrm{a}}$ & $57.78 \pm 1.63^{a}$ & $52.63 \pm 1.22^{\mathrm{b}}$ & $52.00 \pm 1.14^{b}$ \\
\hline Cholest (g/dl) & $1.11 \pm 0.11^{\mathrm{a}}$ & $1.10 \pm 0.04^{a}$ & $1.24 \pm 0.05^{a}$ & $1.31 \pm 0.06^{a}$ \\
\hline Ur acid (g/dl) & $151.00 \pm 6.29^{a}$ & $162.67 \pm 8.78^{a}$ & $152.50 \pm 3.69^{a}$ & $159.80 \pm 6.66^{a}$ \\
\hline TP (mg/dl) & $67.60 \pm 1.35^{a}$ & $70.89 \pm 1.78^{a}$ & $66.38 \pm 2.10^{a}$ & $69.70 \pm 1.40^{a}$ \\
\hline $\mathrm{Na}^{+}(\mathrm{mEq} / \mathrm{L})$ & $139.00 \pm 1.15^{a}$ & $138.78 \pm 0.70^{a}$ & $141.75 \pm 1.29^{a}$ & $139.00 \pm 1.07^{a}$ \\
\hline $\mathrm{K}^{+}(\mathrm{mEq} / \mathrm{L})$ & $4.32 \pm 0.22^{\mathrm{a}}$ & $4.04 \pm 0.21^{\mathrm{a}}$ & $4.38 \pm 0.26^{a}$ & $4.74 \pm 0.24^{a}$ \\
\hline $\mathrm{Cl}^{-}(\mathrm{mg} / \mathrm{dl})$ & $98.40 \pm 0.82^{\mathrm{a}}$ & $98.67 \pm 0.67^{a}$ & $98.25 \pm 0.49^{a}$ & $99.50 \pm 0.58^{a}$ \\
\hline $\mathrm{Ca}^{2+}(\mathrm{mg} / \mathrm{dl})$ & $2.41 \pm 0.03^{a}$ & $2.36 \pm 0.07^{a}$ & $2.42 \pm 0.03^{a}$ & $2.47 \pm 0.03^{a}$ \\
\hline
\end{tabular}

Data was expressed as Mean \pm S.E.M. Means in the same row with different letter superscript are significantly different $(P<0.05)$.

DW: Distilled Water that served as untreated control; AST: Aspartate Aminotransferase; ALT: Alanine Aminotransferase; ALP: Alkaline Phosphotase; TP: Total Protein; Cholest: Cholesterol, Creat: Creatinine

Table 3: Effect of the crude methanol extract of E. hirta combined with honey on blood Biochemical parameters of rats. 
Citation: Onyeka IP, Suleiman MM, Bako SP (2018) Toxicity Effects of Methanolic Extract of Euphorbia hirta-Honey Mixture in Albino Rats. J

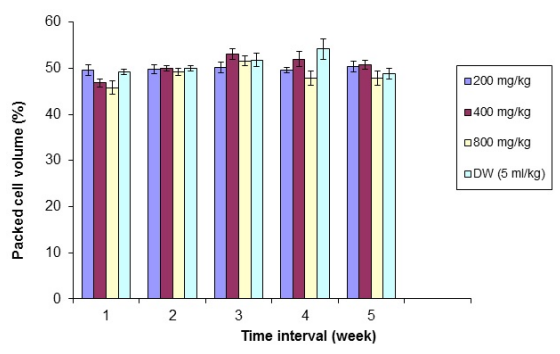

Figure 2: Effect of crude methanol E. hirta extract combined with honey on the packed cell blood of rats. Mean with asterisk $\left(^{*}\right)$ is significantly different $(\mathrm{P}<0.05)$ when compared with untreated control.

\begin{tabular}{|c|c|c|c|c|}
\hline \multirow[t]{2}{*}{ Haematological parameter } & \multicolumn{4}{|c|}{ Treatment (mg/kg) } \\
\hline & 200 & 400 & 800 & DW5 ml/kg \\
\hline $\mathrm{Hb}$ & $14.45 \pm 0.32^{\mathrm{b}}$ & $15.86 \pm 0.33^{a}$ & $15.37 \pm 0.42^{\mathrm{ab}}$ & $16.11 \pm 0.32^{\mathrm{a}}$ \\
\hline RBC & $7.88 \pm 0.30^{\mathrm{b}}$ & $8.74 \pm 0.16^{a}$ & $7.89 \pm 0.22^{b}$ & $8.79 \pm 0.15^{a}$ \\
\hline MCV & $54.50 \pm 1.10^{\mathrm{b}}$ & $54.11 \pm 0.31^{\mathrm{b}}$ & $57.00 \pm 0.50^{a}$ & $54.00 \pm 0.82^{\mathrm{b}}$ \\
\hline $\mathrm{MCH}$ & $18.42 \pm 0.35^{\mathrm{b}}$ & $18.12 \pm 0.14^{b}$ & $19.27 \pm 0.15^{\mathrm{a}}$ & $18.33 \pm 0.23^{b}$ \\
\hline MCHC & $33.61 \pm 0.17^{a}$ & $33.63 \pm 0.27^{a}$ & $33.91 \pm 0.23^{a}$ & $33.96 \pm 0.33^{a}$ \\
\hline WBC & $4.11 \pm 0.14^{b}$ & $4.50 \pm 0.27^{a b}$ & $4.74 \pm 0.11 a$ & $4.63 \pm 0.21^{\mathrm{ab}}$ \\
\hline Platelets & $229.00 \pm 18.79^{b}$ & $246.89 \pm 9.10^{a b}$ & $246.67 \pm 5.78^{a b}$ & $248.78 \pm 15.1^{a}$ \\
\hline
\end{tabular}

Note: Data was expressed as Mean \pm S.E.M. Means in the same row with different letter superscript are significantly different at P<0.05. DW: Distilled water which served as untreated control group.

Note: Hb: Haemoglobin; RBC: Red Blood Cell Count; MCV: Mean Corpuscular Volume; MCHC: Mean Corpuscular Haemoglobin Concentration; MCH: Mean Corpuscular Haemoglobin and WBC: White Blood Cell Count

Table 4: Effect of crude methanolic extract of E. hirta combined with honey on blood hematological parameters of rats. 


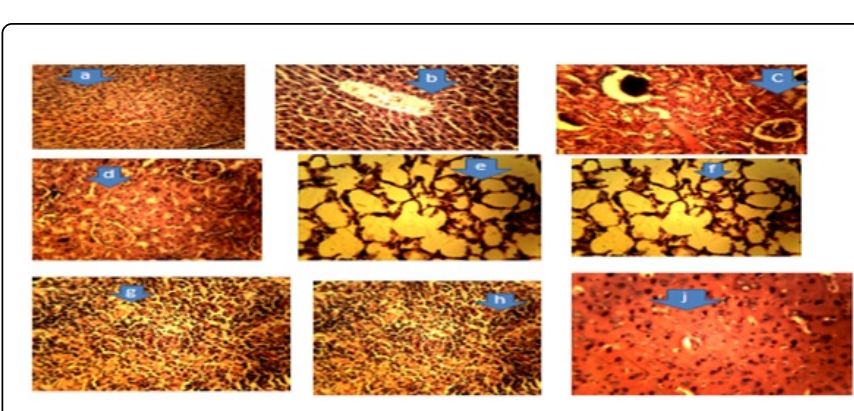

Figure 3: a: Liver micrograph showing slight hepatic necrosis representing rats that received the plant extract of $E$. hirta combined with honey as treatment when compared to; b: Liver micrograph of control that received only normal distilled water. c: The kidney micrograph showing slight glomerular necrosis of the kidney of the rats representing that received plant extract of $E$. hirta combined with honey as treatment when compared to; d: The micrograph of the control that received only distilled water. e: Lungs micrograph showing relatively normal alveoli features of the lungs of animals that received plant extract of $E$. hirta combined with honey as treatment when compared to; f: The lungs of rats that served as control. g: Spleen micrograph showing relatively normal features of the rats that received the plant extract of E. hirta combined with honey as treatment when compared to; h: Animals used as control. The micrograph of heart, intestine and that of the brain all showed normal features when compared with the control. Plate-h reveals the brain micrograph showing normal features.

\section{Discussion}

The use of medicinal plants in treatments of various illness is increasing globally, as it is widely accepted that the use of plantsderived principles will offer access to effective medical care for the treatment and managements of diseases through self-medication [27].

Though honey combination with plant has been traditional used for treatment of ulcer, determination of the safety should be overriding criteria for its use. Examination of the effect extract combined with honey on blood hematological and biochemical parameters was necessary to ascertain the safety of using this phytomedicine.

The result showed a stabilizing effect of the Euphorbia hirta combined with honey on the blood hematological and biochemical parameters, as well as on the vital organs of the body of rats. The stabilizing effect of this combination may be as a result of the cushioning and protective effective of honey combination. This reported is similar with findings of Wilson [28] who reported that honey showed hepato-protective and renal protective effect on rats evidenced by the stability in liver enzymes, and uric acid.

The result of acute toxicity studies showed that the phytomedicine of E. hirta combined with honey has no acute toxicity effect up to the dose of $5000 \mathrm{mg}$ combined with honey in rats. This is in agreement with the findings of Ping, who reported that Euphorbia hirta showed no sign of toxicity or mortality up to $5000 \mathrm{mg} / \mathrm{kg}$ in rats in a 14 days acute toxicity studies and also showed no mortality and no toxic effect at dose level up to $100 \mathrm{mg} / \mathrm{kg}$.

The result fining from our research also suggest that honey combined with $E$. hirta has a synergistically stabilizing effect on the body weight, blood parked cell volume, liver enzymes and the organ weight of the rats at the subchronic level of administration. The stability on the parked cell volume showed that the phytomedicine could have boosted the blood level and hence suggests that the phytomedicine could have anti-anemic potential.

Furthermore the combination showed a stabilizing effect the blood biochemical parameters as evidenced in the results of the AST, ALP, Cholesterol, Uric acid and Blood sodium, Calcium, Chlorine and Potassium Concentration respectively as well as the organ micrograph of brain, intestine, spleen and heart. This means that it has no harmful effect on the blood when administered orally for a long period of time a synergistic potential of this combination.

\section{Conclusion}

The stability in blood parameters and organ weight suggest that the combination of E. hirta with honey is safe for oral ingestion and justified the usage by the Igbo people of South Eastern Nigeria to treat stomach ulcer.

The conclusion from the findings implies that the phytomedicine combination of $E$. hirta combined with honey is safe for consumption and hence has no toxic effect to the vital organs of the body as well as the blood parameters. Therefore the drug is clean and safe for consumption.

\section{References}

1. Akhtar AH, Ahmad KU (1995) Anti-ulcerogenic evaluation of the methanolic extract of some indigenous medicinal plants of Pakistan in aspirin ulcerated rats. J Ethnopharmacol 46: 1-6.

2. Ogbonnia S, Adekunle AA, Bosa MK, Enwuru VN (2008) Evaluation of acute and subacute toxicity of Alstonia congensis Engler (Apocynaceae) bark and Xylopia aethiopica (Dunal) A. rich (Annonaceae) fruits mixtures used in the treatment of diabetes. Afri J Biotechnol 7: 701-705.

3. Ping KY, Darah I, Cheng Y, Sreerananan S, Sasidharan S (2013) Acute and subchronic toxicity study of Euphorbia hirta L. methanol extract in rats. BioMed Res Intl 2013: 1-14.

4. Pieme CA, Penlap VN, Nkegoum B, Taziebou CL, Tekwu EM, et al. (2006) Evaluation of acute and subacute toxicities of aqueous ethanolic extract of leaves of (L) Roxb (Ceasalpiniaceae). Afr J Biotechnol 5: 283-289.

5. Rickert K, Martinez RR, Martinez TT (1999) Pharmacist knowledge of common herbal preparations. Proc West Pharmacol Soc 42: 1-2.

6. Ogbonnia SO, Mbaka GO, Igbokwe NH, Anyika EN, Alli P, et al. (2010) Antimicrobial evaluation, acuteand subchronic toxicity studies of leone bitters, a nigerian polyherbal formulation, in rodents.

7. Emordi EJ, Ogbonnia OS, Olayemi SO, Dozie-Nwanna C, Anyika EN, et al. (2014) Preclinical toxicity study of the phytomedicine-bee honey and Musa paradisiaca extract in rodents. Int J Herbs Pharmacol Res 3: 8-15.

8. Tédong L, Dzeufiet PDD, Dimo T, Asongalem EA, Sokeng SN, et al. (2007) Acute and Subchronic toxicity of Anacardium occidentale Linn (Anacardiaceae) leaves hexane extract in mice. Afr J Trad Alt Med 4: 140-147.

9. Bandaranayake MW (2006) Modern Phytomedicine. In: Turning Medicinal Plants into Drugs. Wiley-VCH Verlag GmbH \& Co. KGaA, Weinheim. ISBN: 3-527-31530-6.

10. Dias FDL, Takahashi CS (1994) Cytogenetic evaluation of aqueous extracts of the medicinal plants Alpinia mutans rose (Zingerberaceae) and Pogostemumhyneanus benth (Labitae) on Wistar rats and Allium cepa (Liliaceae) root tip cells. Brazilian J Genetics 17: 175-180.

11. Ezeoke J (2008) Personal Communication on Traditional Drugs Used For Stomach Disorder :Ulcer. Achala Village Umuchu, Aguata LGA. Anambra State. 
Citation: Onyeka IP, Suleiman MM, Bako SP (2018) Toxicity Effects of Methanolic Extract of Euphorbia hirta-Honey Mixture in Albino Rats. J

Page 8 of 8

12. Tabuti JRS (2008) Euphorbia hirta L. Record from Protabase. Schmelzer GH and Gurib-Fakim A. PROTA (Plant Resources of Tropical Africa Ressources végétales de l'Afrique tropicale) Wageningen, Netherlands. http://database.prota.org/search.htm Accessed 5 December, 2012.

13. Kumar S, Malhotra R, Kumar D (2010) Euphorbia hirta: Its chemistry and medicinal uses, pharmacological activities. Pharmacognosy Rev 4: 58-61.

14. Rajeh MAB, Zuraini Z, Sasidharan S, Latha LY, Amutha S, et al. (2010) Assessment of Euphorbia hirta L. leaf, flower, stem and root extracts for their antibacterial and antifungal activity and brine shrimp lethality. Molecules 15: 6008-6018.

15. Ogbulie JN, Ogueke CC, Okoli IC, Anyanwu BN (2007) Antibacterial activities and toxicological potentials of crude ethanolic extracts of Euphorbia hirta. Afr J Biotechnol 6: 1544-1548.

16. Gyuris A, Szlavik L, Minarovits J, Vasas A, Molnar J, et al. (2009) Antiviral activities of extracts of Euphorbia hirta L. against HIV-1, HIV-2 and SIVmac251. In vivo Int J Exp Clin Parthophysiol Drug Res 23: 429-432.

17. Tona L, Kambu K, Ngimbi N, Mesia K, Penge O, et al. (2000) Antiamoebic and spasmolytic activities of extracts from some Antidiarrhoeal traditional preparations used in Kinshasa and Congo. Phytomed 7: 31-38.

18. Dass P, Mekap S, Pani S, Sethi R, Nayak P, et al. (2010) Pharmacological evaluation of anti-inflammatory activities of Euphorbia hirta Agains Carrageenan induced Paw-edema in rats. Der Pharmacia Lettre 2: 151-154.

19. Mohamed S, Saka S, El-Sharkawy SH, Ali AM, Muid S, et al. (1996) Antimycotic screening of 58 Malaysian plants against plant pathogens. Pesticide Science 47:259-264.
20. White JW (1975) Composition of Honey. In: E Crane (ed) Honey: A Comprehensive Survey. London: Heinemann.

21. Mobarok AA, Al-swayeh AO (1997) Natural honey prevents ethanolInduced increased vascular permeability changes in the rats stomach. J Ethnopharmacol 55: 231-238.

22. Trease GE, Evans WC (1996) Pharmacognosy. $12^{\text {th }}$ edn, Brailers Tindal Ltd, London, pp: 433.

23. Lorke D (1983) A new approach to practical acute toxicity testing. Arch Toxicol 54: 279-287.

24. Atsarno AD, Nguelefack TB, Datte JY, Kamanyi A (2011) Acute and subchronic oral assessment of the aqueous extract from the stem bark of Erythrina senegalensis DC (Fabaceae) in rodents. J Ethnopharmacol 134: 697-702.

25. Waynforth HB (1980) Rats as Laboratory Animals; Surgery, Experimental, Academic Press, New York, NY, USA.

26. Silva AS, Santhiago V, Papoti, M (2007) Hematological parameters and anaerobic thresh in Brazilian soccer players throughout a training program. Int J Lab Hematol 158-166.

27. Lawal B, OK Shittu, A Abubakar, BM Umar, AM Ibrahim, et al. (2015) Biochemical evaluation in wister rats (Rattus novergicus) following chronic exposure of methanol leaf extract of Telfairia occcidentalis. J Pharm Biomed Sci 5: 740-744.

28. Wilson JI, George BO, Umukoro GE (2011) Effects of honey on the histology of liver in adult Wistar rats. Biol Med 3: 1-5. 